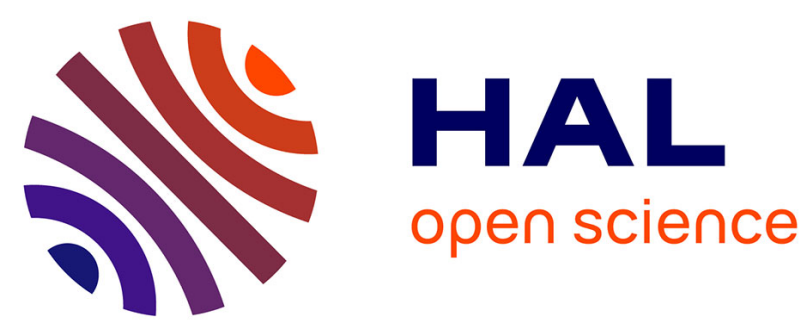

\title{
Unsymmetrical Tetradentate Schiff Base Complexes Derived from 2,3-diaminophenol and Salicylaldehyde or 5-bromosalicylaldehyde
}

Ali Ourari, Kamel Ouari, Wahiba Moumeni, Lakhdar Sibous, Gilles M Bouet, Mustayeen A Khan

\section{To cite this version:}

Ali Ourari, Kamel Ouari, Wahiba Moumeni, Lakhdar Sibous, Gilles M Bouet, et al.. Unsymmetrical Tetradentate Schiff Base Complexes Derived from 2,3-diaminophenol and Salicylaldehyde or 5-bromosalicylaldehyde. Transition Metal Chemistry, 2006, 31, pp.169-175. 10.1007/s11243-0056334-y . hal-03230396

\section{HAL Id: hal-03230396 \\ https://univ-angers.hal.science/hal-03230396}

Submitted on 21 May 2021

HAL is a multi-disciplinary open access archive for the deposit and dissemination of scientific research documents, whether they are published or not. The documents may come from teaching and research institutions in France or abroad, or from public or private research centers.
L'archive ouverte pluridisciplinaire HAL, est destinée au dépôt et à la diffusion de documents scientifiques de niveau recherche, publiés ou non, émanant des établissements d'enseignement et de recherche français ou étrangers, des laboratoires publics ou privés. 


\title{
Unsymmetrical tetradentate Schiff base complexes derived from 2,3-diaminophenol and salicylaldehyde or 5-bromosalicylaldehyde
}

\author{
Ali Ourari, Kamel Ouari, Wahiba Moumeni and Lakhdar Sibous \\ Laboratoire d'Electrochimie, d'Ingénierie Moléculaire et de Catalyse Rédox (LEIMCR), Faculté des Sciences de \\ l'Ingénieur, Université Ferhat Abbas, DZ-19000, Sétif, Algeria
}

Gilles M. Bouet* and Mustayeen A. Khan

SONAS, E.A. 921, Faculté de Pharmacie, 16 Boulevard Daviers, F-49045 and Angers Cedex 01, France

Received 18 July 2005; accepted 30 September 2005

\begin{abstract}
Salicylaldehyde or 5-bromosalicylaldehyde reacted with 2,3-diaminophenol in absolute EtOH in a 2:1 molar ratio to give new unsymmetrical Schiff bases $\left(\mathrm{H}_{2} \mathrm{~L}\right)$. The bases were used as ligands to coordinate $\mathrm{Mn}(\mathrm{III}), \mathrm{Ni}(\mathrm{II})$ and $\mathrm{Cu}(\mathrm{II})$ chlorides leading to $\left[\mathrm{Mn}^{\mathrm{III}} \mathrm{ClL}\right] \cdot \mathrm{EtOH}$ and $\left[\mathrm{M}^{\mathrm{II}} \mathrm{L}\right]$ or $\left[\mathrm{M}^{\mathrm{II}} \mathrm{L}\right] \cdot 2 \mathrm{H}_{2} \mathrm{O}(\mathrm{M}=\mathrm{Ni}$ or $\mathrm{Cu})$ complexes. Their structures were determined using mass spectroscopy, IR, u.v.-vis and ${ }^{1}$ H-n.m.r. The cyclic voltammetry in acetonitrile showed irreversible waves for both ligands. Under the same experimental conditions, the complexes exhibited mainly the non-reversible reduction of the $\mathrm{Ni}(\mathrm{II})$ or $\mathrm{Cu}(\mathrm{II})$ ion to $\mathrm{Ni}(0)$ or $\mathrm{Cu}(0)$, while the reduction of $\mathrm{Mn}$ (III) to $\mathrm{Mn}$ (II) was found to be a quite reversible phenomenon.
\end{abstract}

\section{Introduction}

Since the first report of the Schiff reaction [1], the synthesis of symmetrical tetradentate Schiff bases as ligands, and of their complexes, has been widely described. Some of them may be used as catalysts in various chemical processes [2, 3], or as models for a better understanding of some biological systems [4-6]. However, the unsymmetrical tetradentate Schiff base complexes were less studied than the symmetrical ones.

A large number of publications describing the preparation of the half-units of these unsymmetrical ligands, using various derivatives of salicylaldehyde, have been reported [7-22]. Various tridentate and tetradentate Schiff bases and relative metal complexes were obtained. Among these compounds, some were used as catalysts: for instance, the $\mathrm{Mn}$ (III) complexes of a new chiral unsymmetrical Schiff-base containing salicylaldehyde and (2-hydroxyphenyl)alkylketone units were found to be good catalysts for the asymmetric epoxidation of unfunctionalised alkenes [20]. Similarly, non-symmetrical tetradentate vanadyl Schiff base complexes derived from 1,2-phenylene diamine and 1,8-naphthalene diamine showed catalytic activity in the oxidation of cyclohexene [22].

Another way was also mentioned to synthesise the analogous complexes via the reaction of $\beta$-diketones with $o$-aminophenol (OAP) and its derivatives [23, 24] in order to obtain the half-unit condensed Schiff base.

\footnotetext{
* Author for correspondence: E-mail: gilles.bouet@univ-angers.fr
}

These two latest classes of complexes were not relatively easily obtained.

In the present work, the non-symmetry of the Schiff bases occurs through the diamine moiety e.g. 2,3-diaminophenol. The complexes formed with these two new ligands will be precursors for the synthesis of new materials obtained by etherification of the phenolic hydroxyl. They could be used in several applications, such as the modification of monomers (pyrrole, thiophene etc.) to form, via anodic oxidation, polymers used to build modified electrodes. These new complex species will appear in polymer matrices as pendant functional groups, covalently grafted. The applications of these compounds are very important for electrocatalysis or mainly electroanalysis.

\section{Experimental}

\section{Physical measurements}

The ${ }^{1}$ H-n.m.r. spectra of the ligands and the Ni(II) diamagnetic complexes were recorded with a Bruker AC 250 at $25{ }^{\circ} \mathrm{C}$. All chemical shifts ${ }^{1} \mathrm{H}$ are given in ppm using tetramethylsilane (TMS) as internal reference and $\mathrm{DMSO}_{-} \mathrm{D}_{6}$ as solvent. The i.r. spectra were recorded on a Perkin-Elmer 1000-FT-IR Spectrometer using $\mathrm{KBr}$ discs, while the electronic spectra (u.v.-vis) were obtained on a Unicam UV-300 Spectrophotometer. The melting points were determined with a Kofler bench and were uncorrected. Cyclic voltammograms 
were made with a Tacussel PJT potentiostat Galvanostat driven by Pilovit-Num. All measurements were done in a $5 \mathrm{~cm}^{3}$ Metrohm monocompartment cell equipped with a classical three-electrode. The solvent was acetonitrile with a $10^{-3} \mathrm{~mol}^{-1}$ concentration for the studied species, and the ionic strength was maintained at $0.1 \mathrm{~mol} \mathrm{l}^{-1}$ with $\mathrm{Bu}_{4} \mathrm{NClO}_{4}$ (TBAP). The electrodes were polished with diamond paste and rinsed with large amounts of acetone and finally with acetonitrile. The working electrode was a disc of glassy carbon (diam. $3 \mathrm{~mm}$ ), the counter electrode a $\mathrm{Pt}$ wire, and the reference electrode was a saturated calomel electrode (SCE). The DSC diagrams were obtained with a Shimadzu DSC-60 in the range 20-800 ${ }^{\circ} \mathrm{C}$. The mass spectra (FAB, electrospray) were recorded on a Jeol JMS 70 spectrometer (Service central d'Analyses Spectroscopiques, Université d'Angers, Pr. P. Richomme).

\section{Preparation of the ligands and the complexes}

All chemicals were analytical grade and were used as received without further purification. The metal salts were acetate derivatives.

\section{Preparation of the ligands}

To a solution of absolute EtOH $\left(5 \mathrm{~cm}^{3}\right)$ containing $1 \mathrm{mmol}$ of 2,3-diaminophenol was added $2 \mathrm{mmol}(\mathrm{EtOH}$, $15 \mathrm{~cm}^{3}$ ) of salicylaldehyde or of its derivative. The mixture was stirred under an argon atmosphere and heated at $50{ }^{\circ} \mathrm{C}$ for $1 \mathrm{~h}$. It was kept overnight at $c a .4{ }^{\circ} \mathrm{C}$. The ligand was recovered by filtration and its purity was verified using TLC with a mixture of $\mathrm{CH}_{2} \mathrm{Cl}_{2} / \mathrm{MeOH}(9.5 /$ $0.5, \mathrm{v} / \mathrm{v}$ ) as solvent (Figure 1).

\section{Preparation of the complexes}

The complexes were prepared as previously described [25-27]. To a solution of the ligand $\mathrm{H}_{2} \mathrm{~L} 1$ or $\mathrm{H}_{2} \mathrm{~L} 2$ absolute EtOH $\left(0.5 \mathrm{mmol}, 10 \mathrm{~cm}^{3}\right)$ was added slowly the metal acetate $\left(0.475 \mathrm{mmol}, 5 \mathrm{~cm}^{3} \mathrm{EtOH}\right)$. The mixture was heated for several hours under a $\mathrm{N}_{2}$ atmosphere and finally kept overnight at $4{ }^{\circ} \mathrm{C}$. The complex which precipitated was removed by filtration. It was washed several times with a $\mathrm{MeOH} / \mathrm{H}_{2} \mathrm{O}$ mixture $(1: 1, \mathrm{v} / \mathrm{v})$ previously bubbled with $\mathrm{Ar}$ for 15 min mainly in the case of the manganese(III) complexes.

The manganese complexes were obtained under an air atmosphere in order to oxidise $\mathrm{Mn}(\mathrm{II})$ to $\mathrm{Mn}$ (III) (yield: $70 \%$ ). In this way, the mixture was heated at $50{ }^{\circ} \mathrm{C}$ for $1 \mathrm{~h}$ under an air atmosphere. The acetate group was further exchanged with chloride ions using $\mathrm{LiCl}$ (10 times more concentrated than the complex solution) under stirring at $50{ }^{\circ} \mathrm{C}$ for $1 \mathrm{~h}$.

\section{Results and discussion}

The main analytical data for the complexes is given in Table 1 .

\section{Molecular formulae}

The elemental analysis (Table 1) indicated several molecular formulae: the two $\mathrm{Mn}(\mathrm{III})$ complexes showed

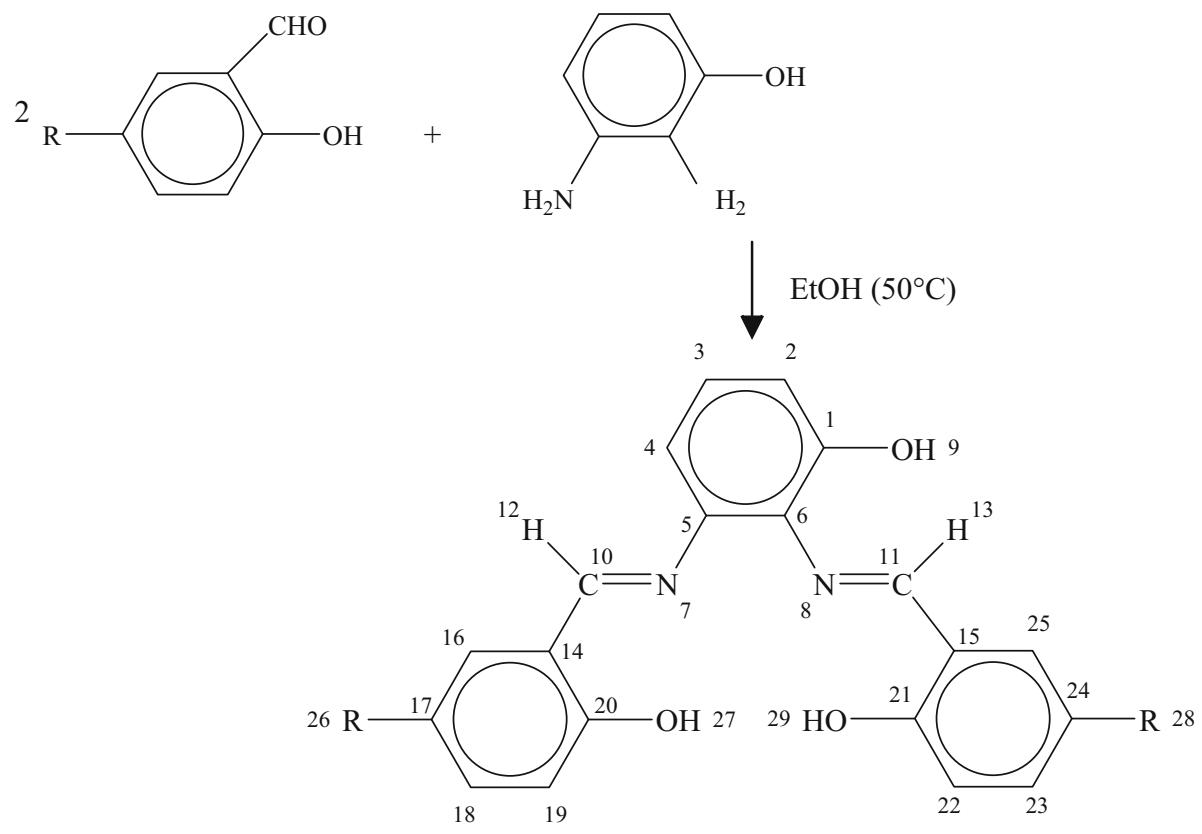

$\mathrm{H}_{2} \mathrm{~L} 1: \mathrm{R}=\mathrm{H}$

$\mathrm{H}_{2} \mathrm{~L} 2: \mathrm{R}=\mathrm{Br}$

Fig. 1. Synthesis pathway for ligands synthesis. 
Table 1. Analytical data for the complexes

\begin{tabular}{|c|c|c|c|c|c|c|}
\hline Compound & Colour & Yield $(\%)$ & $\mathrm{M}^{+}$ & $\mathrm{C}(\%)$ & $\mathrm{H}(\%)$ & $\mathrm{N}(\%)$ \\
\hline $\mathrm{Mn}(\mathrm{III}) \mathrm{ClL} 1 \cdot \mathrm{EtOH}$ & Brown & 70 & & $56.0(56.7)$ & $4.2(4.3)$ & $5.6(6.0)$ \\
\hline $\mathrm{Ni}(\mathrm{II}) \mathrm{L} 1$ & Yellow & 68 & 389.0 & $61.6(61.7)$ & $3.7(3.6)$ & $6.9(7.2)$ \\
\hline $\mathrm{Cu}(\mathrm{II}) \mathrm{L} 1$ & Green & 50 & 394.0 & $57.1(55.9)$ & $3.7(3.7)$ & $7.8(6.5)$ \\
\hline $\mathrm{Mn}(\mathrm{III}) \mathrm{ClL} 2 \cdot \mathrm{EtOH}$ & Brown & 65 & & $42.9(42.3)$ & $2.7(2.9)$ & $4.6(4.5)$ \\
\hline $\mathrm{Ni}(\mathrm{II}) \mathrm{L} 2 \cdot 2 \mathrm{H}_{2} \mathrm{O}$ & Yellow & 80 & 546.9 & $40.1(41.2)$ & $2.4(2.7)$ & $5.6(4.8)$ \\
\hline $\mathrm{Cu}(\mathrm{II}) \mathrm{L} 2 \cdot 2 \mathrm{H}_{2} \mathrm{O}$ & Green & 73 & 551.9 & $37.8(40.8)$ & $3.0(2.7)$ & $4.7(4.8)$ \\
\hline
\end{tabular}

an $\mathrm{EtOH}$ molecule while $\mathrm{Ni}(\mathrm{II})$ and $\mathrm{Cu}(\mathrm{II})$ exhibited 2 water molecules in the case of $\mathrm{H}_{2} \mathrm{~L} 2$ only. All compounds were obtained with the ligand dianion corresponding to the ionisation of the two phenolic groups. The $\mathrm{Ni}(\mathrm{II})$ and $\mathrm{Cu}(\mathrm{II})$ complexes are neutral species while $\mathrm{Mn}(\mathrm{III})$ complexes appear to be cationic species with chloride anion as counter ion. The molecular masses obtained by mass spectroscopy (Table 1) are in good agreement with the proposed formulae and with the literature [28].

\section{Infrared spectra}

The broad absorption which was systematically observed at the $3300-3800 \mathrm{~cm}^{-1}$ range either in the ligands (intra-molecular hydrogen bonding) or in the complexes (water lattice), is assigned to the hydroxyl groups of phenol. In the case of the complexes, this broad band expresses the presence of $\mathrm{H}_{2} \mathrm{O}$ or $\mathrm{EtOH}$ molecules, according to the DSC results, the observation of releasing vapour (loss of $\mathrm{H}_{2} \mathrm{O}$ or EtOH) during the melting point measurements and the elemental analysis [29]. The comparison of the spectra of the free ligands with those of their complexes within the range $1650-1178 \mathrm{~cm}^{-1}$ indicates that the ligands coordinate through $\mathrm{N}$ and $\mathrm{O}$-atoms.

The stretching vibrations $v(\mathrm{C}=\mathrm{N}), \quad v(\mathrm{C}=\mathrm{C})$ and $v(\mathrm{C}-\mathrm{O})$ show very strong bands in the 1615-1602, $1460-1440$ and $1330-1178 \mathrm{~cm}^{-1}$ ranges, respectively. In this case, the band corresponding to the $\mathrm{C}=\mathrm{N}$ stretching vibration for the azomethine group $-\mathrm{N}=\mathrm{CH}-$ $[30-34]$ is shifted to lower wavenumbers $\left(2-12 \mathrm{~cm}^{-1}\right)$, while its intensity decreases. In the meantime the $v(\mathrm{C}-\mathrm{O})$ vibration shifts to higher wavenumbers. These two facts are due to coordination of the metal ion through the oxygen atoms of ionised hydroxyl groups and nitrogen atoms from imino groups $[35,36]$.

\section{Electronic spectra}

In the electronic spectra (Table 2), we note a bathochromic shift in the case of $\mathrm{H}_{2} \mathrm{~L} 1$ when passing from the ligand to the manganese(III) complex Mn(III)ClL1. This bathochromic effect is observed again with all other complexes in this series. As regards the ligands $\mathrm{H}_{2} \mathrm{Ll}$ and $\mathrm{H}_{2} \mathrm{~L} 2$, a bathochromic effect is also noted due to bromide in $\mathrm{H}_{2} \mathrm{~L}$. The molar extinction coefficient $\varepsilon$ maxima is higher for $\mathrm{H}_{2} \mathrm{~L} 2$ because of the extension of the electronic conjugation reaching the d-electrons of bromine atoms electronic shell.

\section{${ }^{1} H$-n.m.r. spectroscopy}

The ${ }^{1}$ H-n.m.r. spectra of ligand $\mathrm{H}_{2} \mathrm{Ll}$ and its nickel complex NiL1 were recorded in DMSO-D . These $^{1} \mathrm{H}-$ n.m.r. results are presented in Table 3 (see Figure 1 for the numbering scheme).

The aromatic protons give a multiplet centred at $7.2 \mathrm{ppm}$ for $\mathrm{H}_{2} \mathrm{~L} 1$ and $7.11 \mathrm{ppm}$ for its nickel complex NiL1. Herein we will attempt to propose some attributions based on the literature [37, 38]. It has been reported that the chemical shift of the hydroxyl proton of 2-hydroxyacetophenone or salicylaldehyde, where the carbonyl group is attached in the $o$-position from the hydroxyl group, resonates at $12.05 \mathrm{ppm}$ [37, 39], shifted more downfield than the phenol proton $(\delta=7.54 \mathrm{ppm})$. This deshielding shift was attributed to the formation of intramolecular hydrogen bonding. Taking account of these considerations [40] for $\mathrm{H}_{2} \mathrm{~L}$, we could assign the signal at $9.94 \mathrm{ppm}$ to $\mathrm{H}(9)$ and the

Table 2. Spectroscopic data

\begin{tabular}{|c|c|c|c|c|c|c|c|c|c|}
\hline \multirow[t]{2}{*}{ Compound } & \multicolumn{3}{|c|}{ Infrared $\left(\mathrm{cm}^{-1}\right)$} & \multicolumn{2}{|l|}{ u.v.-vis } & \multirow[b]{2}{*}{$\lambda(\mathrm{nm})$} & \multirow[b]{2}{*}{$\varepsilon\left(\mathrm{M} \mathrm{cm}^{-1}\right)$} & \multirow[b]{2}{*}{$\lambda(\mathrm{nm})$} & \multirow[b]{2}{*}{$\varepsilon\left(\mathrm{M} \mathrm{cm}^{-1}\right)$} \\
\hline & $v(\mathrm{O}-\mathrm{H})$ & $v(\mathrm{C}=\mathrm{N})$ & $v(\mathrm{C}-\mathrm{O})$ & $\lambda(\mathrm{nm})$ & $\varepsilon\left(\mathrm{M} \mathrm{cm}^{-1}\right)$ & & & & \\
\hline $\mathrm{H}_{2} \mathrm{Ll}$ & 3398 & 1610 & 1210 & 260 & 137100 & 332 & 116400 & & \\
\hline $\mathrm{Mn}(\mathrm{III}) \mathrm{ClL} 1 \cdot \mathrm{EtOH}$ & 3249 & 1602 & 1301 & 336 & 288500 & 434 & 144200 & & \\
\hline $\mathrm{Ni}(\mathrm{II}) \mathrm{L} 1$ & 3475 & 1608 & 1153 & 350 & 135800 & 472 & 77100 & & \\
\hline $\mathrm{Cu}(\mathrm{II}) \mathrm{L} 1$ & 3413 & 1605 & 1228 & 350 & 168400 & 334 & 159400 & 420 & 12490 \\
\hline $\mathrm{H}_{2} \mathrm{~L} 2$ & 3414 & 1615 & 1270 & 266 & 166900 & 350 & 144500 & & \\
\hline $\mathrm{Mn}(\mathrm{III}) \mathrm{ClL} 2 \cdot \mathrm{EtOH}$ & 3412 & 1603 & 1201 & 224 & 101400 & 338 & 48700 & & \\
\hline $\mathrm{Ni}(\mathrm{II}) \mathrm{L} 2 \cdot 2 \mathrm{H}_{2} \mathrm{O}$ & 3375 & 1603 & 1288 & 350 & 199700 & 458 & 106600 & & \\
\hline $\mathrm{Cu}(\mathrm{II}) \mathrm{L} 2 \cdot 2 \mathrm{H}_{2} \mathrm{O}$ & 3412 & 1605 & 1244 & 350 & 80800 & 460 & 53000 & & \\
\hline
\end{tabular}


Table 3. ${ }^{1} \mathrm{H}-$ n.m.r. data of ligands and their nickel complexes in DMSO-D $_{6}$ (Chemical shifts in ppm vs TMS)

\begin{tabular}{|c|c|c|c|c|c|c|}
\hline \multirow[t]{2}{*}{ Compound } & \multicolumn{6}{|c|}{ Hydrogen atoms } \\
\hline & $a^{*}$ & 9 & 29 & 27 & 13 & 12 \\
\hline $\mathrm{H}_{2} \mathrm{~L} 1$ & 7.26 & 9.94 & 12.74 & 13.16 & 8.90 & 8.88 \\
\hline $\mathrm{H}_{2} \mathrm{~L} 2$ & 7.39 & 10.10 & 12.70 & 13.30 & 8.94 & 8.90 \\
\hline $\mathrm{Ni}(\mathrm{II}) \mathrm{L} 1$ & 7.11 & 11.32 & - & - & 9.53 & 8.79 \\
\hline $\mathrm{Ni}(\mathrm{II}) \mathrm{L} 2$ & 7.33 & 10.30 & - & - & 9.90 & 9.27 \\
\hline
\end{tabular}

*a, aromatic protons; the numbering scheme is given in Figure 1 .

signal at $12.74 \mathrm{ppm}$ to $\mathrm{H}(29)$ seeing that both interact with the same nitrogen atom of the azomethine group. In the meantime, the peak at 13.16 is assigned to $\mathrm{H}(27)$ which interacts exclusively with the nitrogen atom of the second azomethine group. In this ligand $\left(\mathrm{H}_{2} \mathrm{~L} 1\right)$, we have also observed a very weak difference between the azomethine protons $\mathrm{H}(12)$ and $\mathrm{H}(13)$ which appear at 8.8 and $8.9 \mathrm{ppm}$ respectively, for the same reasons than those previously indicated for the hydroxyl proton of 2-hydroxyacetophenone [40]. This difference becomes more important in the corresponding nickel complex NiL1 where the signals of the azomethine protons arise at 9.53 for $\mathrm{H}(13)$ and at 8.79 for $\mathrm{H}(12)$. This fact is supported by a higher structure rigidity, leading to the co-planarity of the different $\mathrm{sp}^{2}$ systems constituting the complex according to the square planar generally observed for nickel complexes [41]. Reciprocally, this deshielding shift at $9.94 \mathrm{ppm}$ for $\mathrm{H}(9)$ in $\mathrm{H}_{2} \mathrm{~L} 1$, and at $11.32 \mathrm{ppm}$ for NiL1, probably, due to the intramolecular hydrogen bonding between the phenol proton $\mathrm{H}(9)$ and the nitrogen atom of the azomethine group. These results are in good agreement with those previously reported in the literature [21, 22, 37-39, 41].

\section{DSC diagrams}

The DSC diagrams show significant differences between ligands and complexes. For all species, decomposition occurs at temperatures higher than $300{ }^{\circ} \mathrm{C}$. Some exothermic processes occur previously in the $200-240{ }^{\circ} \mathrm{C}$ range; according to the nature of the complex. It must also be indicated that these compounds lose their $\mathrm{H}_{2} \mathrm{O}$ or solvent molecules giving an endothermic peak under an air flux around $200{ }^{\circ} \mathrm{C}$ in the case of the complexes. This is in good agreement with values given in literature [28].

\section{Mass spectrometry}

Positive ions corresponding to the different complexes $\left[\mathrm{M}^{+}\right]$were identified by the $\mathrm{FAB}^{+}$method (Fast atom bombardment). The spectra of these complexes also show peaks attributed to $\left[\mathrm{M}^{+}+1 \mathrm{H}^{+}\right]$and $\left[\mathrm{M}^{+}+2 \mathrm{H}^{+}\right]$, respectively. These results agree with the expected structures and the data reported in literature [29].

\section{Electrochemical characteristics of the ligands and the complexes}

The cyclic voltammetric data of the ligands and the complexes are summarised in Table 4 and some representative curves are given in Figure 2.

\section{Ligands}

In the -2.200 to $+2.200 \mathrm{~V}$ range, the ligand $\mathrm{H}_{2} \mathrm{~L} 1$ shows, two irreversible waves on the anodic side, with $E \mathrm{p}_{\mathrm{a} 1}=+1.060$ and $E \mathrm{p}_{\mathrm{a} 2}=+1.520 \mathrm{~V}$ respectively, without any cathodic peaks. These two irreversible waves are attributed to the para and ortho oxidations of the phenol moieties and of the phenol groups themselves [42]. The same phenomenon is observed for $\mathrm{H}_{2} \mathrm{~L} 2$ but these two oxidation waves are located at +1.440 and $+1.840 \mathrm{~V}$. This ligand presents an improved resistance towards oxidation reactions due to para-bromine atoms leading to higher oxidation potential values because the para and ortho positions of the phenol moieties presents a lower electronic density. These results are very close to those reported in the literature for similar compounds [42-45].

\section{Complexes}

The Mn(III) complexes show only one reduction wave located at $-0.360 \mathrm{~V}$ for $\mathrm{H}_{2} \mathrm{Ll}$ and at $-0.040 \mathrm{~V}$ in the case of $\mathrm{H}_{2} \mathrm{~L} 2$. The reoxidation of these species occurs at -0.240 and $+0.080 \mathrm{~V}$, respectively. So the $\mathrm{Mn}$ (III)

Table 4. Voltamperometric results at $25{ }^{\circ} \mathrm{C}$ in $\mathrm{MeCN}$, ionic strength $0.1 \mathrm{~mol}^{-1}$ (TBAP), results in $\mathrm{V}$ vs $\mathrm{SCE}$, sweep speed: $50 \mathrm{mV} \mathrm{s}^{-1}, E_{\mathrm{a}}$ : anodic; $E_{\mathrm{c}}$ : cathodic

\begin{tabular}{lllllllll}
\hline Complex & $E_{\mathrm{pa} 1}$ & $E_{\mathrm{pa} 2}$ & $E_{\mathrm{pa} 3}$ & $E_{\mathrm{pc} 1}$ & $E_{\mathrm{pc} 2}$ & $i_{\mathrm{pa}} / i_{\mathrm{pc}}$ & $\Delta E^{\mathrm{a}}$ & $E_{1 / 2} \mathrm{~b}$ \\
\hline $\mathrm{Mn}(\mathrm{III}) \mathrm{ClL} 1 \cdot \mathrm{EtOH}$ & -0.240 & & & -0.360 & & 0.780 & -0.120 & -0.300 \\
$\mathrm{Ni}(\mathrm{II}) \mathrm{L} 1$ & -0.960 & +1.16 & & -0.880 & -1.660 & 0.260 & -0.700 & -0.760 \\
$\mathrm{Cu}(\mathrm{II}) \mathrm{L} 1$ & +0.840 & +0.960 & +1.420 & -0.880 & -1.600 & 0.367 & -0.120 & +0.020 \\
$\mathrm{Mn}(\mathrm{III}) \mathrm{ClL} 2 \cdot \mathrm{EtOH}$ & +0.080 & & & -0.040 & & 0.833 & -0.560 & -0.540 \\
$\mathrm{Ni}(\mathrm{II}) \mathrm{L} 2 \cdot 2 \mathrm{H}_{2} \mathrm{O}$ & -0.840 & +1.150 & +1.760 & -0.780 & -1.400 & 0.620 & \\
$\mathrm{Cu}(\mathrm{II}) \mathrm{L} 2 \cdot 2 \mathrm{H}_{2} \mathrm{O}$ & -0.50 & +1.360 & +1.740 & & -1.300 & 0.727 & \\
\hline
\end{tabular}

${ }^{\mathrm{a}} \Delta E=E_{\mathrm{pc}}-E_{\mathrm{pa}}$.

${ }^{\mathrm{b}} E^{1 / 2}=0.5 \Delta E+E_{\mathrm{pa}}$. 

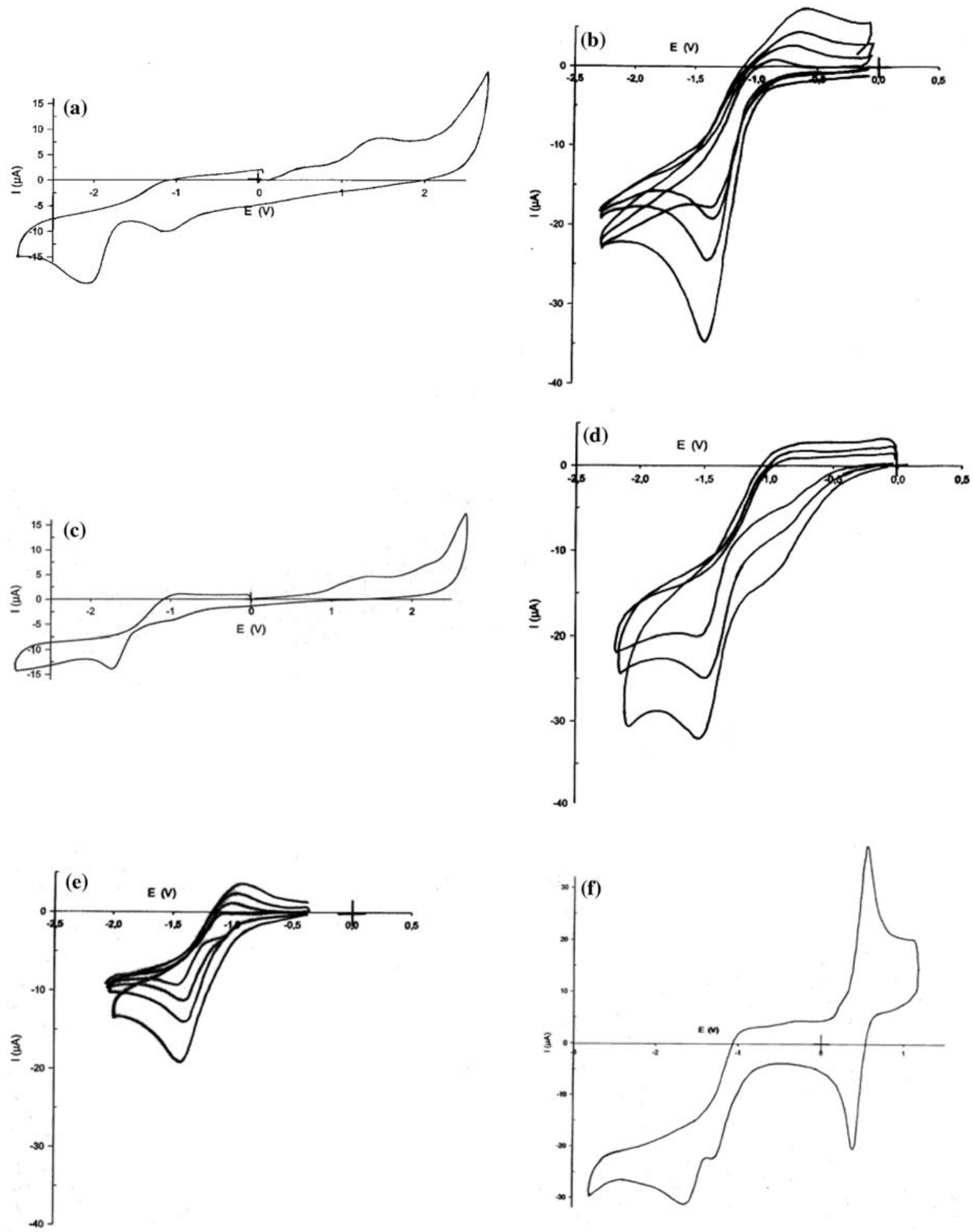

Fig. 2. Voltammograms of NiL1 (a), NiL2 (c) scan rate $5 \mathrm{~m} \mathrm{~V} \mathrm{~s}^{-1}$; NiL1 (b), NiL2 (d), and CuL2 (e) with variable scan rate; CuL2 with ferrocene (f) in $\mathrm{MeCN}\left(\mu=0.1 \mathrm{~mol} \mathrm{l}^{-1}\right)$.

complexes show diffusion controlled quasi-reversible couples: $\mathrm{Mn}(\mathrm{III}) \mathrm{ClL} / \mathrm{Mn}(\mathrm{II}) \mathrm{ClL}(\mathrm{L}=\mathrm{L} 1$ or $\mathrm{L} 2)$. The variation of the scan rate $\left(v=100\right.$ to $\left.500 \mathrm{~V} \mathrm{~s}^{-1}\right)$ shows that the curve $E_{\mathrm{pc}}$ as a function of $\log v$ is a straight line and it does not depend upon the sweep speed. The potential peaks separation is $\Delta E_{\mathrm{p}}=0.120 \mathrm{~V}$ and the $i_{\mathrm{pa}} / i_{\mathrm{pc}}$ ratios are close to 1 . The acceptor effect of $p$-bromine substituent in Mn(III)ClL1 shifts the half- wave potential from $-0.300 \mathrm{~V}$ (in $\mathrm{Mn}$ (III)ClL1 5,5'not substituted) to $+0.020 \mathrm{~V}$ (Mn(III)ClL2, 5,5'-brominated) as previously described [27].

The reduction waves of nickel(II) complexes are located at $-1.660 \mathrm{~V}$ (ligand $\mathrm{H}_{2} \mathrm{~L} 1$ ) and $-1.400 \mathrm{~V}$ (ligand $\left.\mathrm{H}_{2} \mathrm{~L} 2\right)[46,47]$. When the speed rate changes, this single reduction wave is sometimes decomposed into two steps and the second peak is often more clear than 


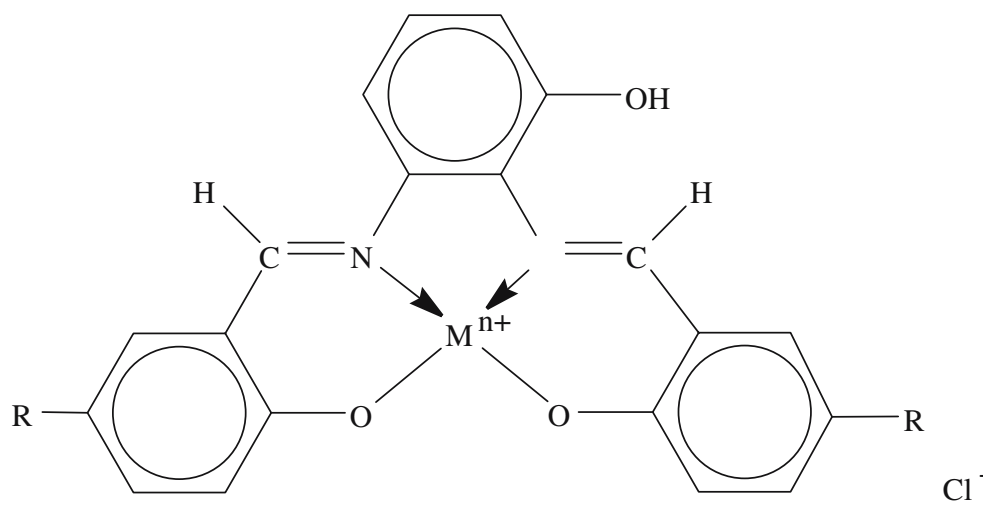

$\mathrm{M}=\mathrm{Mn}(\mathrm{n}=3)$ with $\mathrm{Cl}^{-}$or $\mathrm{Ni}$ or $\mathrm{Cu}(\mathrm{n}=2)$ without $\mathrm{Cl}^{-}$

Fig. 3. Proposed structures for the complexes: $\mathrm{R}=\mathrm{H}\left(\mathrm{H}_{2} \mathrm{~L} 1\right)$ or $\mathrm{Br}\left(\mathrm{H}_{2} \mathrm{~L} 2\right)$.

the first. These two successive reduction waves are observed in the $\mathrm{CV}$ of $\mathrm{Ni}(\mathrm{II}) \mathrm{L} 2$ at various scan rates $(100$ to $10 \mathrm{mV} \mathrm{s}^{-1}$ ) but $\mathrm{Ni}(\mathrm{II}) \mathrm{L} 1$ gives only one wave in any case. A similar behaviour has been found for the corresponding copper complexes.

Two reduction waves are also observed for $\mathrm{Cu}(\mathrm{II}) \mathrm{L} 1$ at all scan rates but, in the case of $\mathrm{Cu}(\mathrm{II}) \mathrm{L} 2$, they appear clearly in the 25 to $5 \mathrm{~m} \mathrm{~V} \mathrm{~s}^{-1}$ range only. The peaks separation between this anodic wave and the corresponding anodic peak $\Delta E_{\mathrm{p}}$ is greater than $0.500 \mathrm{~V}$; this value is higher than those reported for a Nernstian process. Nevertheless, these voltamperograms exhibit a pair of anodic and cathodic peaks showing a chemical reversibility with a chemical reaction associated to the electrochemical processes as indicated by the shape of the curve Ip vs. scan rate square root (not shown).

When ferrocene is added, very few changes occur in the $\mathrm{CV}\left(i_{\mathrm{p}}\right.$ or $\left.E_{\mathrm{p}}\right)$ for $\mathrm{Ni}(\mathrm{II})$ complexes. In the case of $\mathrm{Mn}(\mathrm{III})$ compounds, the cathodic current intensity was enhanced by $50 \%$. Ferrocene should be used as a good external reference for the electrochemical study of these manganese compounds; it will be also useful for their detection at low concentrations. For $\mathrm{Cu}$ (II) complexes, the intensities of the two cathodic waves are $30 \%$ higher when ferrocene is added. In the meantime, the $E_{\mathrm{pcl}}$ value remains unchanged while the second $E_{\mathrm{pc}}$ peak is shifted by $0.180 \mathrm{~V}$ on the cathodic side.

\section{Proposed structures}

The proposed structures for the complexes are given in Figure 3. The $\mathrm{Mn}(\mathrm{III})$ (cationic) and $\mathrm{Ni}(\mathrm{II})$ (neutral) complexes are square planar species. In the case of the $\mathrm{Mn}^{3+}$ compounds a positive charge remains and the chloride ion is located outside the complex structure. In the copper complexes, the metal ion presents a distorted octahedral geometry with the two ligands in a plane and two $\mathrm{H}_{2} \mathrm{O}$ molecules along the $z$-axis of the complex (ligand $\mathrm{H}_{2} \mathrm{~L} 2$ ). In the $\mathrm{Cu}(\mathrm{II})$ complex the copper ion presents a square planar geometry.

\section{References}

1. H.S. Schiff, Ann. Chim. (Paris), 131, 118 (1864).

2. R.A. Sheldon and J.K. Kochi, Metal Catalysed Oxidation of Organic Compounds, Academic Press, New York, 1981.

3. (a) J.P. Costes, G. Gros and M.H. Darbieu, Inorg. Chim. Acta, 60, 111 (1982); (b) T.G. Traylor, Y.S. Byun, P.S. Traylor, P. Battioni and D. Mansuy, J. Am. Chem. Soc., 113, 7821 (1991).

4. (a) J.P. Costes, G. Gros, M.H. Darbieu and Y.P. Laurent, Transition Met. Chem., 7, 219 (1982), (b) D. F. Averill and R.F. Broman, Inorg. Chem., 17, 3389 (1978).

5. P.R. Ortiz de Montellano, Cytochrome P-450, Structure, Mechanism and Biochemistry, Plenum Press, New York - London, 1986; (b) V. Ullrich, I. Roots, A. Hildebrandt, R.W. Estabrook and A.H. Cooney (Ed.), Micrososomes and Drug Oxidations, Pergamon Press, New York, 1975, p. 795; (c) D. Mansuy, Pure App. Chem., 59, 759 (1987).

6. (a) B. Halliwell and J.M.C. Gutterigde, Free Radicals in Biology and Medicine, 2nd edit., Clarendon Press, Oxford, 1988, p. 543; (b) J.E. Kovacic, Spectrochim. Acta, 23A, 183 (1987).

7. R. Roy, S.K. Mondal and K. Nag, J. Chem. Soc., Dalton Trans., 1935 (1983).

8. L. Casella, Inorg. Chem., 23, 2781 (1984).

9. E. Kwiatkowski and M. Kwiatkowski, Inorg. Chim. Acta, 82, 101 (1984).

10. R.T. Roy, M. Chaudhury, S.K. Mondal and K. Nag, J. Chem. Soc., Dalton Trans., 1681 (1984).

11. R. Atkins, G. Brewer, E. Kokot, G.M. Mockler and E. Sinn, Inorg. Chem., 24, 128 (1985).

12. E.G. Jage and D. Seidel, Z. Chem., 25, 28 (1985).

13. M. Kwiatkowski and E. Kwiatkowski, J. Chem. Soc., Dalton Trans., 803 (1985)

14. P. Leoni, E. Crilli, M. Pasquali and M. Tomassini, J. Chem. Soc., Dalton Trans., 879 (1986).

15. I. Sasaki, D. Pujol and A. Gaudemer, Inorg. Chim. Acta, 134, 53 (1987).

16. M.S. Mashuta, T.N. Doman, W. Pierce and R. Buchanan, Inorg. Chim. Acta, 145, 21 (1988).

17. E. Kwiatkowski, M. Kwiatkowski, A. Olechnowicz, S. Mronzinski, D.M. Ho and E. Deutsh, Inorg. Chim. Acta, 158, 37 (1989).

18. L. Casella, M. Gullotti, E. Suardi, M. Sisti, R. Pagliarinand and P. Zanello, J. Chem. Soc., Dalton Trans., 2843 (1990).

19. (a) R. Bastida, A. De Blas, T. Rodriguez, A. Sousa and D.E. Fenton, Inorg. Chim. Acta, 203, 1 (1993); (b) R. Bastida, A. de Blas, D.E. Fenton, C. Rial, T. Rodriguez and A. Sousa, J. Chem. Soc., Dalton Trans., 265 (1993).

20. P. Pietikainen and A. Haikarainen, J. Mol. Catal. A, 180, 59 (2002).

21. D.M. Boghaei and S. Mohebi, J. Mol. Catal. A, 179, 41 (2002). 
22. D.M. Boghaei and S. Mohebi, Tetrahedron, 58, 5357 (2002).

23. (a) J. P. Costes and G. Gros, C. R. Séances Acad. Sci., Sér. II, 294, 173 (1982); (b) R.C. Combes, J.P. Costes and D.E. Fenton, Inorg. Chim. Acta, 77, L173 (1983).

24. E. Kwiatkowski, M. Klein and G. Romanoski, Inorg. Chim. Acta, 293, 115 (1999).

25. L.J. Boucher and D.R Herrington, Inorg. Chem., 13, 1105 (1974).

26. T. Matsushita, H. Kono and T. Shono, Bull. Chem. Soc. Jpn., 54, 2646 (1981).

27. J.C. Moutet and A. Ourari, Electrochim. Acta, 42, 2525 (1977).

28. J. Sanmartin, M.R. Bermejo, A.M. Garcia-Deibe, M. Maniero, C. Lage and A.J. Costa-Filho, Polyhedron, 19, 185 (2000).

29. I.V. Korendovych and E.V. Rybak-Akimova, Acta. Cryst. C, C60, 82 (2004)

30. P. Gili, M.G. Martin-Reyes, P. Martin-Zarza, I.L.F. Machado, M.F.C. Guedes da Silva, M.A.N.D.A. Lemos and A.J.L. Pombiero, Inorg. Chim. Acta, 244, 25 (1996).

31. L.J. Bellamy, The Infrared Spectra of Complex Molecules, 3rd edit., Chapman and Hall, London, 1975, p. 52.

32. P. Gili, M.G. Martin-Reyes, P. Martin-Zarza, I.L.F. Machado, M.F.C. Guedes da Silva, Y.Y. Tong and A.J.L. Pombeiro, Inorg. Chim. Acta, 255, 279 (1996).

33. A. Vogt, S. Wolowiec, R.L. Prasad, A. Gupta and J. Skarzewski, Polyhedron, 17, 1231 (1998).

34. Z. Cimerman, N. Galic and B. Bosner, Anal. Chim. Acta, 343, 145 (1997).
35. R.C. Felicio, G.A. Da Silva, L.F. Ceridorio and E.R. Dockal, Synth. React. Inorg. Met.-Org. Chem., 29, 171 (1999).

36. S.M. Abu-El-Wafa, R.M. Issa and C.A. McAuliffe, Inorg. Chim. Acta, 99, 103 (1985).

37. M.M. Abd-Elzaher, J. Chin. Chem. Soc., 48, 153 (2001).

38. M. Gulloti, L. Casella, A. Pasini and R. Ugo. J. Chem. Soc., Dalton Trans., 339 (1977).

39. K.H. Chang, C.C. Huang, Yi.H. Liu, Y.H. Hu, P.T. Chou and Y. Chih, J. Chem. Soc., Dalton Trans., 1731 (2004).

40. R.M. Silverstein, G.C. Bassler and T.C. Morrill, Spectrometric Identification of Organic Compounds, 4th edit., John Wiley and Sons, New-York, p. 196 (1981).

41. G. Maki, J. Chem. Phys., 28, 651 (1958).

42. E.T.G. Cavalheiro, F.C.D. Lemos, J. Zukerman Schpector and E.R. Dockal, Thermochim. Acta, 370, 129 (2001).

43. L. Papouchado, G. Petrie, J.H. Sharp and R.N. Adams, J. Am. Chem. Soc., 90, 5620 (1968).

44. U. Svanholm, K. Bechgaard and V.D. Parker, J. Am. Chem. Soc., 96, 2409 (1974).

45. E.J. Land, G. Porter and E. Strachan, Trans. Faraday Soc., 57, 1885 (1961).

46. J. Losada and L. Beyer, Transition Met. Chem., 25, 112 (2000).

47. J. Losada, I. del Peso and L. Beyer, J. Electroanal. Chem., 447, 147 (1998).

TMCH 6334 